\title{
HAEMATOLOGICAL PROFILE IN MICROCYTIC HYPOCHROMIC ANAEMIA IN CHILDREN
}

\author{
Raju Kafle, ${ }^{1}$ Anupama Bastola, ${ }^{2}$ Ashok P Samdurkar, ${ }^{2}$ Narayan Gautam, ${ }^{3}$ Anuj Poudel, ${ }^{2}$ Anita Shahi ${ }^{2}$
}

\begin{abstract}
\section{INTRODUCTION}

The most common disorders presenting with microcytic hypochromic anaemia are iron deficiency anaemia (IDA) and $\beta$ Thalassemia trait ( $\beta$-TT), and each of them has different pathogenesis and treatment modality. Here we intend to see the haematological profile in microcytic hypochromic anaemia in children apart from IDA and Thalassemia with respect to age and gender.
\end{abstract}

\section{MATERIAL AND METHODS}

A total of 95 pediatric patients between the ages of 2 to 12 years with microcytic hypochromic anaemia were included in the study. Blood samples obtained from each patient were evaluated for various haematological and biochemical profiles along with haemoglobin electrophoresis. It was a hospital based observational cross-sectional study done for a period of 18 months from January 2019 to July 2020.

\section{RESULTS}

Severe anaemia was seen in $55(57.89 \%)$ cases, followed by $38(40.00 \%)$ cases with moderate anaemia and $2(2.11 \%)$ cases with mild anaemia. Majority of the cases showed IDA, which were $85(89.5 \%)$ cases, followed by $6(6.3 \%)$ cases with $\beta$-TT and 4 (4.2\%) cases with $\beta$-TM. RBC count, hematocrit and RDW showed significant variation between IDA, $\beta$ TM and $\beta$-TT. Most number of correctly diagnosed cases were shown by Ricerca Index with 90 (94.74 \%).

\section{CONCLUSION}

Our study concludes RBC count and RDW, along with Srivasthava Index, Ricerca Index and RDW Index could be used as reliable indices to differentiate between iron deficiency anaemia and $\beta$-Thalassemia. Red cell indices, serum iron profile and haemoglobin electrophoresis complement each other for the precise diagnosis of underlying cause of microcytic hypochromic anaemia.

\section{KEYWORDS}

Microcytic hypochromic anaemia, Iron deficiency anaemia (IDA), $\beta$-Thalassemia, Redcell indices, Discriminating indices

1 Department of Paediatrics, Universal College of Medical sciences, Bhairahawa, Nepal

2 Department of Pathology, Universal College of Medical sciences, Bhairahawa, Nepal

3 Department of Biochemistry, Universal College of medical sciences, Bhairahawa, Nepal

DOI: https://doi.org/10.3126/jucms.v9i02.41941

For Correspondence
Dr. Raju Kafle
Department of Pediatrics
Universal College of Medical Sciences
Bhairahawa, Nepal
Email: ddrrajukafle2@gmail.com




\section{INTRODUCTION}

Anaemia is one of the most common conditions encountered by a physician on daily basis, whether clinically apparent or not.' There are various ways of classifying anaemia, and among them classification based on size of RBCs is commonly used. The most common disorders presenting with microcytic hypochromic anaemia are iron deficiency anaemia (IDA) and $\beta$-Thalassemia trait $\left(\beta\right.$-TT), ${ }^{2,3}$ other common causes can be chronic diseases and lead poisoning. It has been shown that in the developing countries, $80 \%$ of the children become anemic at some point of time by the age of 18 years. According to demographic health survey of Nepal, 2016, where $95 \%$ of 2,272 children were successfully tested, the prevalence of anaemia among children 6-59 months was $53 \%$, which appears comparable to WHO's report on global prevalence of anaemia 2011, in South East Asian region, with $53.8 \%$. Studies conducted in adolescents of Nepal also shows that, irrespective of gender, more than $50 \%$ are suffering from IDA. ${ }^{5}$ WHO also reports decrease in anaemia by significant number, (42\%) of total anemic children, if iron supplementation is adequate.

Several red cell indices obtained from electronic cell counters have been used as the first indicators of IDA and $\beta$ Thalassemia. Definitive differential diagnosis between these is based on serum iron profile and haemoglobin electrophoresis. However, some areas with endemic thalassemia have poor health care resources such as our region of study and hence, these tests are not readily accessible as they are deemed to be too expensive or time consuming or both.

For this matter, a number of discriminating indices have been proposed since 1970, which are simple and inexpensive tools for determining whether a blood sample is more suggestive of $\beta$-Thalassemia or IDA. Some of the commonly used discriminating indices are Mentzer Index, ${ }^{8}$ Shine and LalIndex, England Fraser Index, ${ }^{10}$ Srivasthava Index, ${ }^{11}$ and RDW Index. ${ }^{12}$ Currently, in our setting, CBC obtained from semiautomated cell counter and peripheral blood smear for $\mathrm{RBC}$ morphology are being used for screening microcytic hypochromic anaemia.

Several studies have been conducted, in different countries regarding reliability of discriminating indices for the definitive diagnosis of microcytic hypochromic anaemia, which have yielded variable results. ${ }^{13-15}$ Our study hopes to find reliable discriminating indices for diagnosis of microcytic hypochromic anaemia in Western region of Nepal for providing with a simple and cost-effective method for definitive diagnosis. Nepal being a Southeast Asian country, falls in underdeveloped part of the world. The people of Nepal do not have easy access to health facilities and are not always able to afford expensive investigations. So, our study also aims to determine a reliable index for confirmatory diagnosis of microcytic hypochromic anaemia, using commonly available red cell indices.

\section{MATERIAL AND METHODS}

Total 95 Patients aged 2 to 12 years attending the OPD/IPD of Department of Pediatrics of UCMS-TH Bhairahawa, Nepal, presenting with microcytic hypochromic anaemia, confirmed by CBC and PBS were selected for study from January 2019 to June 2020. This was a hospital based, observational crosssectional study. On the ground of wide variation in prevalence of anaemia in Nepal among the different age group of children, the proportion of microcytic hypochromic anaemia was taken as $43.4 \%$, based on the study done in Eastern part of Nepal. ${ }^{16}$ With adjusted minimum sample size, at $95 \%$ confidence interval 90 is the sample size here we took 95 cases.

Peripheral smear with dimorphic picture, history of blood transfusion within past two months and children on hematinic and other types of anaemia except microcytic hypochromic anaemia were excluded from study. The study was approved by institutional research committee (IRC) of UCMS-TH (UCMS/IRC/234/18). Written and verbal informed consents were obtained in each case from the guardian or the primary care taker who agreed for the study. Seven discriminating red cell indices were calculated using predetermined formulas for each case. Anaemia was categorized into mild, moderate and severe based on WHO.

Clinical diagnosis of all cases of microcytic hypochromic anaemia were taken and findings were noted. Specific variables were defined for proper evaluation. Every case was reported by a pathologist, using Olympus BX-53 microscope. Biochemical investigations were performed whenever indicated. Reference values for serum iron and other iron panel study were taken as standard value for male and female. ${ }^{17}$

Reference normal values of $\mathrm{HbA}, \mathrm{HbA} 2$ and $\mathrm{HbF}$ were taken $\mathrm{as}^{18}: \mathrm{HbA}:>95 \%, \mathrm{HbA} 2: 2-3 \%, \mathrm{HbF}:<1$. Age, gender, laboratory investigations $(\mathrm{Hb}, \mathrm{RBC}$ count, Haematocrit, $\mathrm{MCV}, \mathrm{MCH}, \mathrm{MCHC}$, RDW, PBS, Serum Iron profile, HB electrophoresis) were the study variables. SPSS version 25 was used for analysis of data. For descriptive statistics, frequency, percentage, mean and Standard Deviation (S.D.) were calculated. Categorical data were compared by chisquare test. ANOVA test and independent t-test were applied to analyze the association between variables at $95 \%$ Confidence Interval (CI). Level of significance for all analytical tests was set at 0.05 and $p$ value $<0.05$ was considered significant. 


\section{RESULTS}

A total of 95 patients aged 2-12 years, with microcytic hypochromic anaemia were evaluated with $\mathrm{CBC}, \mathrm{PBS}$, serum iron profile and haemoglobin electrophoresis along with proper clinical details; $52(54.7 \%)$ cases were between age group 2-6 years and $43(45.3 \%)$ cases were in between $6-12$ years; majority of cases were males with $51(53.7 \%)$, male to female ratio was 1.16:1.

\section{A. HEMATOLOGICAL PARAMETERS}

\section{I) Severity of anaemia}

Based on WHO criteria for mild, moderate and severe anemia, according to age, majority of the cases in our study were noted to have severe anaemia, seen in $55(57.89 \%)$ cases. Case distribution according to severity of anaemia in different age group is shown in Table 1 . In this study, least $\mathrm{Hb}$ was 2.4 $\mathrm{gm} / \mathrm{dl}$, seen in a 5-year-old female, eventually diagnosed as IDA. Maximum $\mathrm{Hb}$ was $10.71 \mathrm{gm} / \mathrm{dl}$, of 9-year-old female, also diagnosed as IDA.

Table 1. Case distribution according to severity of anaemia $(\mathrm{N}=95)$

\begin{tabular}{lcccc}
\hline \multicolumn{1}{c}{ Severity of anaemia } & \multicolumn{3}{c}{ Age groups (years) } & \multirow{2}{*}{$\begin{array}{c}\text { Total } \\
\mathbf{n}(\%)\end{array}$} \\
\cline { 2 - 3 } & <5 years & $\mathbf{5 - 1 1 \text { years }}$ & $\mathbf{1 2}$ years & \\
\hline Mild anaemia n (\%) & $2(2.11)$ & - & - & $2(2.11)$ \\
Moderate anaemia n (\%) & $12(12.63)$ & $21(22.11)$ & $5(5.26)$ & $38(40.00)$ \\
Severe anaemia n (\%) & $13(13.68)$ & $40(42.10)$ & $2(2.11)$ & $55(57.89)$ \\
Total n (\%) & $27(28.42)$ & $61(64.21)$ & $7(7.37)$ & $95(100)$ \\
\hline
\end{tabular}

\section{II) Mean Corpuscular Volume (MCV)}

In this study, minimum MCV found was $38.7 \mathrm{fl}$, in a 9-yearold female, diagnosed as IDA and maximum MCV noted was $80.4 \mathrm{fl}$, in a 5 years male, diagnosed as $\beta$-TM. Similar pattern was seen for $\mathrm{MCH}, \mathrm{MCHC}$.

Out of 95 cases studied, $82(86.3 \%)$ cases had RDW $>14$, whereas, 13 (13.7\%) cases had RDW <14. Minimum RDW noted was $12 \%$, seen in a 5 -year-old male patient, diagnosed as $\beta$-TM and maximum RDW noted was $24 \%$, seen in a $3-$ year-old female patient, diagnosed as IDA.

\section{III) Serum Iron panel and Hematological variables}

Out of 95 cases, $81(85.2 \%)$ had low ferritin level, Similar pattern was seen with total iron binding capacity (TIBC), total serum iron, and transferrin saturation. Analysis of haematological variables according to age is as shown in Table 2 .
Table 2. Analysis of haematological variables according to age $(\mathrm{N}=95)$

\begin{tabular}{|c|c|c|c|c|}
\hline \multirow{2}{*}{$\begin{array}{c}\text { Haematological } \\
\text { variables } \\
\text { (Mean } \pm \text { S.D.) }\end{array}$} & \multicolumn{2}{|c|}{ Age (years) } & \multirow{2}{*}{$\begin{array}{c}\text { Total } \\
(\text { Mean } \pm \text { S.D. })\end{array}$} & \multirow[t]{2}{*}{$p$ value } \\
\hline & 2-6 years & 7-12 years & & \\
\hline $\mathrm{Hb}(\mathrm{gm} / \mathrm{dl})$ & $6.74 \pm 2.19$ & $7.11 \pm 2.11$ & $6.91 \pm 2.14$ & 0.461 \\
\hline RBC count $\left(10^{12} / \mathrm{l}\right)$ & $3.22 \pm 1.22$ & $3.48 \pm 0.85$ & $3.34 \pm 1.06$ & 0.022 \\
\hline Hematocrit (\%) & $19.85 \pm 7.10$ & $22.90 \pm 5.69$ & $21.23 \pm 6.61$ & 0.046 \\
\hline MCV (fl) & $62.72 \pm 8.40$ & $61.90 \pm 9.31$ & $62.35 \pm 8.74$ & 0.830 \\
\hline MCH (pg) & $19.03 \pm 3.71$ & $18.66 \pm 2.94$ & $18.86 \pm 3.35$ & 0.025 \\
\hline $\mathrm{MCHC}(\mathrm{gm} / \mathrm{dl})$ & $25.02 \pm 4.19$ & $29.50 \pm 1.59$ & $27.05 \pm 3.94$ & 0.0001 \\
\hline RDW (\%) & $16.19 \pm 2.88$ & $17.15 \pm 1.74$ & $16.63 \pm 2.45$ & 0.040 \\
\hline Serum Iron $(\mu \mathrm{g} / \mathrm{dl})$ & $46.45 \pm 66.88$ & $35.29 \pm 45.06$ & $41.40 \pm 57.71$ & 0.102 \\
\hline TIBC $(\mu \mathrm{g} / \mathrm{dl})$ & $405.58 \pm 60.88$ & $415.14 \pm 41.43$ & $409.91 \pm 52.64$ & 0.075 \\
\hline Ferritin (ng/dl) & $37.34 \pm 87.70$ & $22.33 \pm 71.13$ & $30.55 \pm 80.14$ & 0.184 \\
\hline $\begin{array}{l}\text { Transferrin } \\
\text { Saturation }(\%)\end{array}$ & $14.63 \pm 28.55$ & $9.94 \pm 16.91$ & $12.51 \pm 23.86$ & 0.086 \\
\hline
\end{tabular}

B. ASSOCIATION OF PERIPHERAL SMEAR FINDING WITH DIAGNOSIS OF MICRO CYTIC HYPOCHROMIC ANAEMIA

In this study, on microscopic examination of each peripheral smear, poikilocytosis was found in the form of tear drop cells, target cells and elliptocytes. There was significant variation with presence of tear drop cells ( $p$ value $<0.05$ ).

On poikilocytosis examination in cases, tear drop cells were seen in $78(82.11 \%)$ cases, where majority of cases with tear drop cells were IDA, with $74(77.90 \%)$ cases. There was significant variation in distribution of number of $\mathrm{nRBCs} / 100$ WBCs counted in peripheral smears.

\section{HAEMOGLOBIN ELECTROPHORESIS}

\section{i) Variants of haemoglobin}

When haemoglobin electrophoresis was done in suspected $\beta$ Thalassemia cases, out of 10 cases, low $\mathrm{HbA}(<90 \%)$ was found in all $10(100 \%)$ cases. HbA2 was increased $(>3 \%)$ in 6 $(60 \%)$ cases and was normal $(1-3 \%)$ in $4(40 \%)$ cases whereas $\mathrm{HbF}$ was increased $(>1 \%)$ in all $10(100 \%)$ cases.

\section{ii) Mean value of haemoglobin variants in $\beta$-TM and $\beta$-TT}

Among the 10 cases of $\beta$-Thalassemia, mean $\mathrm{HbA}$ and $\mathrm{HbA} 2$ varied significantly in between $\beta$-TM and $\beta$-TT ( $p$ value $<0.05$ ), whereas there was no significant variation of $\mathrm{HbF}$ ( $p$ value $>0.05$ ). When t-test was applied, mean $\mathrm{HbA}$ was highest in $\beta$-TT as compared to $\beta$-TM ( $p$ value $=0.049)$. Mean $\mathrm{HbA} 2$ was higher in $\beta$-TT as compared to $\beta$-TM ( $p$ value $=0.0370$ ). 


\section{DISCRIMINATING INDICES}

In present study, while calculating the discri minating indices, the maximum number of correctly diagnosed cases were shown by Ricerca Index with 90 (94.74\%) cases, followed by Mentzer Index with 89 (93.68\%) cases. In this study, only Srivasthava Index showed $100 \%$ sensitivity for diagnosing $\beta$ Thalassemia, $100 \%$ specificity for diagnosing IDA, $100 \%$ positive predictive value for IDA and $100 \%$ negative predictive value for $\beta$-Thalassemia.

\section{DISCUSSION}

This study explored the utility of different haematological parameters, serum iron profile, haemoglobin electrophoresis, peripheral smear and red cell indices in the diagnosis of microcytic hypochromic anaemia and their diagnostic accuracy. In this present study, pediatric age group patients were included aged 2-12 years with slight majority of them were between the ages of 2 to 6 years making $54.7 \%$ of the total cases. This finding is similar to the age distribution seen in the study done by Ghosh $\mathrm{A}$ et $\mathrm{al}^{19}$ where, the largest number of patients with microcytic hypochromic anaemia was 1-6 years age group.

Majority of the cases $(89.5 \%)$ showed microcytic hypochromic anaemia due to iron deficiency, followed by $\beta$ Thalassemia trait $(6.3 \%)$ and $\beta$-Thalassemia major (4.2\%). This finding is similar to the finding in the study conducted by Looker AC et al, ${ }^{20}$ who found that IDA was more prevalent in children as compared to $\beta$-Thalassemia. This is an expected observation as early childhood is a period of rapid growth and depletion of blood iron.

In present study, mean RBC count, hematocrit and RDW vary significantly between IDA, $\beta$-TM and $\beta$-TT, whereas, mean haemoglobin, $\mathrm{MCV}, \mathrm{MCH}$ and $\mathrm{MCHC}$ did not show significant variation among IDA, $\beta$-TM and $\beta$-TT. Study by Viswanath $\mathrm{D}$ et $\mathrm{al}^{21}$ found that RDW was highly sensitive in detecting IDA. These findings are similar to our study, where RDW was found to be statistically significant to discriminate between IDA and $\beta$ Thalassemia.

\section{RED CELL INDICES AND THEIR USES}

Regarding discriminating indices, in this study, the greatest number of correctly diagnosed cases was shown by Ricerca Index with $90(94.74 \%)$ cases followed by Mentzer Index $(93.68 \%)$. These inter-population differences in validity of different indices for discrimination of $\beta$-Thalassemia trait from iron deficiency could be due to the differences of molecular spectrum of $\beta$-Thalassemia disorders in various countries.

\section{CONCLUSION}

In conclusion, $\mathrm{Hb}$ electrophoresis, serum iron profile, and red cell indices are complementary to each other in the precise diagnosis of microcytic hypochromic anaemia of varied etiology. Our study reinforces the usefulness of haematological profile in the diagnosis of microcytic hypochromic anaemia in children and accurate identification of its cause. In spite of relative increased cost, such investigations can be invaluable for prompt and accurate diagnosis of microcytic hypochromic anaemia in children so that appropriate therapy can be instituted at the earliest.

\section{CONFLICT OF INTEREST}

None

\section{REFERENCES}

1. Boopathy T, Subathra J, Sangeetha N, Karthika VV. Haematological profile in microcytic hypochromic anaemia in children. IOSR J Dent Med Sci. 2017;16(1):100-4.

2. Borgna-Pignatti C, Galanello R. Thalassemias and related disorders: quantitative disorders of hemoglobin synthesis. In: Greer JP, Arber DA, Glader B, List AF, Means RTJ, Paraskevas F, et al., editors. Wintrobe's Clinical Hematology. 13th ed. Lippincott Williams and Wilkins; 2014. p. 862-913.

3. Wharton $\mathrm{B}$ a. Iron deficiency in children: detection and prevention. Br J Haematol. 1999; 106(2):270-80.

4. Irwin JJ, Kirchner JT. Anemia in children. Am Fam Physician. 2001;64(8):1379-86.

5. Baral KP, Onta SR. Prevalence of anemia amongst adolescents in Nepal: a community based study in rural and urban areas of Morang District. Nepal Med Coll J. 2009;11(3):179-82.

6. WHO. The global prevalence of anaemia in 2011. Geneva, Switzerland; 2015.

7. Vehapoglu A, Ozgurhan G, Demir AD, Uzuner S, Nursoy MA, Turkmen $\mathrm{S}$, et al. Hematological indices for differential diagnosis of beta thalassemia trait and iron deficiency anemia. Anemia. 2014;2014:1-7.

8. Mentzer WCJ. Differentiation of iron deficiency from thalassemia trait. Lancet. 1973;1:882.

9. Shine I, Lal S. A strategy to detect beta-thalassaemia minor Lancet. 1977;1:692-4.

10. England JM, Fraser PM. Differentiation of Iron Deficiency From Thalassæmia Trait By Routine Blood-Count. Lancet. 1973;1:449-52.

11. Srivastava PC. Differentiation of thalassemia minor from iron deficiency. Lancet. 1973;2:155-6. 
12. Bessman JD, Feinstein DI. Quantitative anisocytosis as a discriminant between iron deficiency and thalassemia minor. Blood. 1979 Feb;53(2):288-93.

13. Sirdah M, Tarazi I, Najjar EAL, Haddad RAL. Evaluation of the diagnostic reliability of different $\mathrm{RBC}$ indices and formulas in the differentiation of the $\beta$-thalassaemia minor from iron deficiency in Palestinian population. Int $\mathrm{J}$ Lab Hematol. 2008;30(4):324-30.

14. Ntaios G, Chatzinikolaou A, Saouli Z, Girtovitis F, Tsapanidou M, Kaiafa G, et al. Discrimination indices as screening tests for $\beta$-thalassemic trait. Ann Hematol. 2007;86:487-91.

15. Nalbanto lu B, Güzel S, Büyükyalçin V, Donma MM, Güzel EC, Nalbanto lu A, et al. Indices used in differentiation of thalassemia trait from iron deficiency anemia in pediatric population: Are they reliable? Pediatr Hematol Oncol. 2012;29(5):472-8.

16. Khatiwada S, Lamsal M, Gelal B, Gautam S, Nepal AK, Brodie $\mathrm{D}$, et al. Anemia, Iron Deficiency and Iodine Deficiency among Nepalese School Children. Indian J Pediatr. 2015;83(7):617-21.

17. Weippl G, Pantlitschko M, Bauer P, Lund S. SerumeisenNormalwerte und statistische Verteilung der Einzelwerte bei Mann und Frau. Blut. 1973;27(4):261-9.

18. Shoushtari AN, Parameswaran R. Benign Hematology. In: Pocket Oncology (Pocket Notebook Series). 1st ed.

19. Ghosh A, Ghartimagar D, Thapa S, Sathian B, De A. Microcytic hypochromic anemia in pediatric age Group: A Hospital based study in Nepal. Am J Public Heal Res. 2015;3(4A):57-61.

20. Looker AC, Dallman PR, Carroll MD, Gunter EW, Johnson CL. Prevalence of iron deficiency in the United States. J Am Med Assoc. 1997;277(12):973-6.

21. Viswanath D, Hegde R, Murthy V, Nagashree S, Shah R. Red cell distribution width in the diagnosis of iron deficiency anemia. Indian J Pediatr. 2001;68:1117-9. 